\title{
Brooklawnia cerclae gen. nov., sp. nov., a propionate-forming bacterium isolated from chlorosolvent-contaminated groundwater
}

Correspondence
William M. Moe
moemwil@lsu.edu

From 1969 until 1980, petrochemical wastes were disposed of by direct discharge to earthen ponds at the Brooklawn site, one of two areas that comprise what is now known as the Petro-Processors of Louisiana, Inc. Superfund Site, located near Baton Rouge (LA, USA). Although portions of the Brooklawn area were capped in the early 1990s and an array of wells was installed to recover contaminants, chlorosolvents remain in the subsurface both as soluble constituents within the groundwater and as non-aqueous-phase liquid (Clement et al., 2002; US Environmental Protection Agency, 2005). The contaminants include 1,1,2,2-tetrachloroethane, 1,1,2-trichloroethane, 1,2-dichloroethane, 1,2-dichloropropane, hexachloro-1,3-butadiene, hexachlorobenzene, vinyl

Abbreviation: DAP, diaminopimelic acid.

The GenBank/EMBL/DDBJ accession number for the 16S rRNA gene sequence of strain BL-34 ${ }^{\top}$ is $\mathrm{DQ} 196625$. chloride and polycyclic aromatic hydrocarbons (Clement et al., 2002; US Environmental Protection Agency, 2005). During a study aimed at characterizing the microbial population present within the non-aqueous-phase liquid source zone at the Brooklawn site, two novel bacterial strains, subsequently designated $\mathrm{BL}-34^{\mathrm{T}}$ and $\mathrm{BL}-35$, were isolated from chlorosolvent-contaminated anaerobic groundwater collected from well W-1024-1 of the site.

Strain BL- $34^{\mathrm{T}}$ was isolated on nutrient agar (Difco), supplemented with L-cysteine $\left(0.5 \mathrm{~g} \mathrm{l}^{-1}\right)$ as a reductant and resazurin $\left(1 \cdot 0 \mathrm{mg} \mathrm{l}^{-1}\right)$ as a redox indicator, adjusted to $\mathrm{pH} 7 \cdot 0$ prior to autoclaving. Incubation was at $30^{\circ} \mathrm{C}$ in an anaerobic chamber (COY Instruments) containing a gas mixture comprising $\mathrm{H}_{2} / \mathrm{CO}_{2} / \mathrm{N}_{2}$ (10:10:80, by vol.). Strain BL35 was isolated on plate-count agar (Difco) with the same supplements and incubated under the same conditions. The purity of each strain was verified by microscopy after 
multiple transfers. The strains were maintained on Colombia anaerobic sheep blood agar (CSBA) plates (BBL) or peptone/ yeast extract/glucose (PYG) agar plates (Akasaka et al., 2003). For comparison purposes, Propionibacterium freudenreichii NRRL B- $3523^{\mathrm{T}}$ was obtained from the Agricultural Research Service Culture Collection (Peoria, IL, USA).

Morphological features were observed using transmission electron microscopy (1000CX; JEOL) after negative staining with uranyl acetate $(2 \%, v / v)$. Endospore production and motility were observed using phase-contrast microscopy (Optiphot; Nikon). Gram-staining, catalase, oxidase and nitrate-reduction tests were performed as described by Smibert \& Krieg (1981). For the nitrate-reduction tests, cells were anaerobically incubated for 2 weeks at $30^{\circ} \mathrm{C}$ in PYG medium amended with $10 \mathrm{mM}$ sodium nitrate. Carbonutilization tests were performed in $16 \mathrm{ml}$ Hungate tubes containing $10 \mathrm{ml}$ PY medium (Akasaka et al., 2003) and a headspace of $\mathrm{N}_{2} / \mathrm{CO}_{2}(95: 5, \mathrm{v} / \mathrm{v})$. Each substrate was added at a concentration of 5 or $10 \mathrm{~g} \mathrm{l}^{-1}$ for monosaccharides, disaccharides and polysaccharides and sugar alcohols and at 15 or $30 \mathrm{mM}$ for organic acids. Cultures were inoculated using $1 \%(\mathrm{v} / \mathrm{v})$ exponentially growing seed culture grown in PYG. Cultures were recorded as positive if they exhibited an increase in optical density of more than $0 \cdot 1$ OD unit at $660 \mathrm{~nm}$ relative to controls (which lacked any added carbon sources). The $\mathrm{pH}$ range for growth in PYG was evaluated from $\mathrm{pH} 3 \cdot 0$ to $10 \cdot 0$, using the following buffers: $100 \mathrm{mM}$ acetate buffer for $\mathrm{pH} 3 \cdot 0-6 \cdot 0 ; 100 \mathrm{mM}$ potassium phosphate buffer for $\mathrm{pH} 6 \cdot 0-8 \cdot 0$; and Tris buffer for $\mathrm{pH} 8 \cdot 0-10 \cdot 0$. Growth with $\mathrm{NaCl}$ at $0-5 \%(\mathrm{w} / \mathrm{v})$ and growth at $5-45^{\circ} \mathrm{C}$ were determined in Hungate tubes containing $10 \mathrm{ml}$ PYG. To determine whether vitamin $B_{12}$ stimulated growth of strains BL-34 ${ }^{\mathrm{T}}$ and BL-35, the cultures were grown in PYG medium with and without the addition of $10 \mu \mathrm{g}$ vitamin $\mathrm{B}_{12} \mathrm{l}^{-1}$.

The ability of the strains to use chlorosolvents as electron acceptors was tested in $25 \mathrm{ml}$ serum bottles containing $10 \mathrm{ml}$ anaerobic basal medium (Sung et al., 2003) and headspace gas consisting of $\mathrm{N}_{2} / \mathrm{CO}_{2} / \mathrm{H}_{2}(80: 10: 10$, by vol.); the bottles were sealed with Teflon-lined butyl rubber stoppers and aluminium crimp seals. Basal medium in each bottle was amended with acetate, lactate and pyruvate $(2 \mathrm{mM}$ each) as potential carbon and energy sources and one of the following chlorosolvents as a potential electron acceptor (each 2.0 $\mu \mathrm{mol}$ ): 1,1,2,2-tetrachloroethene, 1,1, 2-trichloroethane, 1,2-dichloroethane, trichloroethene, cis1,2-dichloroethene or 1,2-dichloropropane. Exponentially growing cells cultured in PYG broth were used as inocula. Uninoculated bottles served as negative controls. Bottles were incubated in the dark at $30^{\circ} \mathrm{C}$. The ability of the strains to degrade aromatic compounds under anaerobic conditions was tested using $25 \mathrm{ml}$ serum bottles containing $10 \mathrm{ml}$ anaerobic basal medium (Sung et al., 2003) amended with $0.5 \mu \mathrm{mol}$ benzene, toluene, ethylbenzene or $p$-xylene. The concentrations of the chlorosolvents and aromatic compounds were measured using a gas chromatograph (HP6890; Hewlett Packard) equipped with a capillary column $(60 \mathrm{~m} \times 0.32 \mathrm{~mm}$ i.d., J\&W P/N 1134362; GS-Gaspro) and a flame-ionization detector.

The ability of strains BL- $34^{\mathrm{T}}$ and BL-35 to grow in the presence of various concentrations $(0-9.8 \mathrm{mM})$ of 1 , 2-dichloroethane or 1,1,2-trichloroethane was tested in $120 \mathrm{ml}$ serum bottles containing $80 \mathrm{ml}$ PYG supplemented accordingly. The PYG used for strain BL-35 was also supplemented with $10 \mu \mathrm{g}$ vitamin $\mathrm{B}_{12} \mathrm{l}^{-1}$. The gas headspace mixture was $\mathrm{N}_{2} / \mathrm{CO}_{2}(95: 5, \mathrm{v} / \mathrm{v})$.

The fermentation products from cultures grown anaerobically in PYG medium were analysed by ion chromatography using Metrohm peak 761 compact apparatus equipped with a Metrosep organic acid column $(25 \mathrm{~cm} \times 7 \cdot 8 \mathrm{~mm})$ and a conductivity detector. Isocratic elution was performed with $0.5 \mathrm{mM} \mathrm{H}_{2} \mathrm{SO}_{4}$ at a flow rate of $0.5 \mathrm{ml} \mathrm{min}^{-1}$ and at a constant temperature of $25^{\circ} \mathrm{C}$.

Extraction of genomic DNA, PCR amplification and sequencing of $16 \mathrm{rRNA}$ genes were carried out as described by Rainey et al. (1996). Purified sequencing-reaction products were electrophoresed using a model 3100 DNA sequencer (Applied Biosystems). The 16S rRNA gene sequences of strains BL-34 ${ }^{\mathrm{T}}$ and BL-35 were aligned against previously determined actinobacterial sequences from the database of the National Center for Biotechnology Information (http://www.ncbi.nlm.nih.gov) using BioEdit, version 4.7.8 (Hall, 1999) and CLUSTAL X (Thompson et al., 1997). Phylogenetic analyses were performed using ARB (Strunk \& Ludwig, 1995; http://www.arb-home.de/). The neighbour-joining algorithm was used to construct the phylogenetic tree from distance matrices calculated with the Jukes-Cantor correction (Jukes \& Cantor, 1969). A bootstrap analysis was performed using PHYLIP, version 3.62 (Felsenstein, 2004; http://evolution.genetics.washington.edu/ phylip.html), with 1000 resamplings.

Cells for the analysis of fatty acids were harvested from cultures grown at $30^{\circ} \mathrm{C}$ in PYG under anaerobic conditions for 3 days following inoculation with a $1 \%(\mathrm{v} / \mathrm{v})$ volume of exponentially growing culture. Fatty acids were extracted as described by White et al. (1979). The total lipid extract was fractionated by using silicic acid chromatography, and the polar fraction was transesterified to fatty acid methyl esters and analysed by gas chromatography/ mass spectrometry (Guckert et al., 1985). Menaquinones were extracted and analysed via HPLC by the Identification Services of the Deutsche Sammlung von Mikroorganismen und Zellkulturen (DSMZ; Braunschweig, Germany) using the method described by Tindall (1990a, b). The occurrence of diaminopimelic acid in the cell wall and the peptidoglycan type were analysed by the Identification Services of the DSMZ, as described by Schleifer \& Kandler (1972), using TLC on cellulose plates with the solvent system of Rhuland et al. (1955). The genomic DNA G + C content was determined by HPLC as described by Mesbah et al. (1989) following DNA isolation as described by Nielsen et al. (1995). 
After 13 days anaerobic incubation on CSBA plates at $30^{\circ} \mathrm{C}$, strains BL- $34^{\mathrm{T}}$ and BL-35 formed white, circular, convex, smooth-surfaced colonies that were 1-2 $\mathrm{mm}$ in diameter. Better growth was observed on PYG agar: the colonies were identical in morphology to those grown on CSBA except that they were larger in size $(2-3 \mathrm{~mm}$ in diameter) after a shorter period of incubation (4 days). No spore formation or motility was observed. The cells exhibited pleomorphic rod-type morphologies and were Gram-positive, catalasepositive and oxidase-negative. No nitrate reduction was observed. Growth occurred on nutrient agar, PYG agar and R2A agar (Difco) under both aerobic and anaerobic conditions; however, better growth was obtained under anaerobic conditions. Propionate and acetate were the predominant fermentation products detected in PYG cultures. The temperature range for growth was $10-40{ }^{\circ} \mathrm{C}$, with an optimum of $37^{\circ} \mathrm{C}$. The $\mathrm{pH}$ range for growth was $4 \cdot 5-8 \cdot 0$, with optimal growth at $\mathrm{pH} 6 \cdot 5$. Growth was sustained in the presence of $\mathrm{NaCl}$ at concentrations ranging from 0 to $3 \%(\mathrm{w} / \mathrm{v})$.

The results of additional physiological tests are given in the species description and in Table 1 . Strains BL- $34^{\mathrm{T}}$ and BL35 exhibited identical features except for the fact that the latter required vitamin $B_{12}$ supplementation for optimal growth in PYG under anaerobic conditions. No degradation of chlorosolvents (1,1,2-trichloroethane, 1,2-dichloroethane, 1,1,2,2-tetrachloroethane, trichloroethene, cis-1, 2-dichloroethene, 1,2-dichloropropane) or aromatic hydrocarbons (benzene, toluene, ethyl benzene, p-xylene) was detected under anaerobic conditions, even after incubation for 3 months.

Although strains BL- $34^{\mathrm{T}}$ and BL-35 were unable to biotransform the chlorosolvents tested in this study, both grew well in PYG media in the presence of 1,2-dichloroethane and 1,1,2-trichloroethane at concentrations up to at least $9 \cdot 8 \mathrm{mM}$. The fermentation products produced by strains $\mathrm{BL}-34^{\mathrm{T}}$ and $\mathrm{BL}-35$ in the presence of high chlorosolvent concentrations were the same as those produced in the absence of chlorosolvents. The fact that the strains are able to grow even in the presence of very high chlorosolvent concentrations probably explains why these micro-organisms are able to survive in the dense non-aqueous phase liquid (DNAPL) source zone from which they were isolated.

The major cellular fatty acids in both isolates were anteiso$\mathrm{C}_{15: 0}\left(51 \cdot 9 \%\right.$ for BL-34 ${ }^{\mathrm{T}}$ and $61.4 \%$ for BL-35) and $\mathrm{C}_{15: 0}$ $\left(33.2 \%\right.$ for BL- $34^{\mathrm{T}}$ and $24 \cdot 7 \%$ for BL-35). Minor cellular fatty acids included $\mathrm{C}_{14: 0}$, iso- $\mathrm{C}_{14: 0}, \mathrm{C}_{15: 1}, \mathrm{C}_{16: 0}$, iso- $\mathrm{C}_{16: 0}$, $\mathrm{C}_{16: 1} \omega 7 c, \mathrm{C}_{17: 0}$, iso- $\mathrm{C}_{17: 0}$ and anteiso- $\mathrm{C}_{17: 0}$ (Table 1). The predominant respiratory quinone was $\mathrm{MK}-9\left(\mathrm{H}_{4}\right)$. The peptidoglycan type was $\mathrm{A} 1 \gamma$, with meso-diaminopimelic acid (meso-DAP) in the cell wall. The genomic DNA G +C contents of BL- $34^{\mathrm{T}}$ and BL-35 were $67 \cdot 5$ and $67 \cdot 9 \mathrm{~mol} \%$, respectively.

A neighbour-joining tree constructed on the basis of comparison of 1363 nucleotide positions showed that strains $\mathrm{BL}-34^{\mathrm{T}}$ and BL-35 belong to the family Propionibacteriaceae, clustering with Propionimicrobium lymphophilum DSM $4903^{\mathrm{T}}$ (Stackebrandt et al., 2002) and uncultured bacterial clones N40 and GLY2B01 derived from anaerobic bioreactors (GenBank accession numbers AB195901 and AB244748) (Fig. 1). Environmental 16S rRNA clones N40 and GLY2B01 show the highest levels of sequence similarity with strains BL-34 ${ }^{\mathrm{T}}$ and BL-35 (95.7-96.0\%). Strains BL- $34^{\mathrm{T}}$ and BL-35 had identical $16 \mathrm{~S}$ rRNA gene sequences over the 1459 nucleotide positions determined in this study.

Strains BL- $34^{\mathrm{T}}$ and BL-35 are most closely related to species of the genera Propionimicrobium, Propionibacterium, Luteococcus, Propioniferax and Tessaracoccus within the family Propionibacteriaceae. The type strain of Propionimicrobium lymphophilum (Stackebrandt et al., 2002), the only species of the genus, clusters together with BL- $34^{\mathrm{T}}$ and BL-35 in the phylogenetic analysis and shows $93.5 \%$ sequence similarity (Fig. 1). Members of the genus Propionimicrobium are clearly distinguishable from strains $\mathrm{BL}-34^{\mathrm{T}}$ and BL-35 by their chemotaxonomic properties, i.e. by the presence of lysine rather than meso-DAP in the cell wall, by having $\mathrm{C}_{18: 1} \omega 9 \mathrm{c}(30 \%)$ as the predominant cellular fatty acid and by having a lower DNA G $+C$ content (53-56 mol\%) (Table 1).

The genus Propionibacterium comprises 11 species with validly published names. The phylogenetic position of four of these species is shown in Fig. 1 , and strains BL- $34^{\mathrm{T}}$ and BL-35 are clearly outside the radiation of this genus. Although most of the species contain LL-DAP, a feature that clearly distinguishes them from strains $\mathrm{BL}-34^{\mathrm{T}}$ and BL-35, it was reported that the type species, Propionibacterium freudenreichii, and some strains of Propionibacterium acnes and Propionibacterium avidum contain meso-DAP (Cummins \& Johnson, 1986). Strains BL- $34^{\mathrm{T}}$ and BL-35, however, can be differentiated from the type species of the genus Propionibacterium by their cellular fatty acid composition (the presence of $\mathrm{C}_{18: 1}, \mathrm{C}_{21: 0}$ and $\mathrm{C}_{22: 0}$ as well as the markedly different content of iso- $\mathrm{C}_{14: 0}$, anteiso$\mathrm{C}_{15: 0}$ and iso- $\mathrm{C}_{16: 0}$ in the latter) (Table 1). Additionally, no species of the genus Propionibacterium show more than $94 \%$ $16 \mathrm{~S}$ rRNA gene sequence similarity (Fig. 1) to strains BL$34^{\mathrm{T}}$ and BL-35, suggesting that strains BL-34 ${ }^{\mathrm{T}}$ and BL-35 are distantly related to them and should be classified within a different genus. Additional distinguishing characteristics of the type species Propionibacterium freudenreichii, as well as the more closely related Propionibacterium propionicum, are listed in Table 1.

The genus Luteococcus currently contains three species with validly published names, namely Luteococcus japonicus Tamura et al. 1994 (the type species), L. sanguinis Collins et al. 2003 and L. peritonei Collins et al. 2000, which represent a distinct phylogenetic branch unrelated to strains BL$34^{\mathrm{T}}$ and BL-35 (Fig. 1). They are also easily distinguished from strains $\mathrm{BL}-34^{\mathrm{T}}$ and $\mathrm{BL}-35$ by the chemotaxonomic features of diaminopimelic acid and the cellular fatty acids. Specifically, all Luteococcus species contain LL-DAP, and the predominant fatty acids of the type species, L. japonicus, 
Taxa: 1, strain BL-34 ${ }^{\mathrm{T}}$ (data from this study); 2, strain BL-35 (this study); 3, Propionimicrobium lymphophilum (Stackebrandt et al., 2002); 4, Propionibacterium freudenreichii (Cummins \& Johnson, 1986; Kusano et al., 1997; this study) (the fatty acid composition of strain NRRL B-3523 ${ }^{\mathrm{T}}$ was determined in this study following cell growth under the same conditions and using the same analytical techniques as for strains BL-34 ${ }^{\mathrm{T}}$ and BL-35); 5, Propionibacterium propionicum (Cummins \& Moss, 1990; Maszenan et al., 1999); 6, Luteococcus japonicus (Tamura et al., 1994; Maszenan et al., 1999); 7, Tessaracoccus bendigoensis (Maszenan et al., 1999); 8, Propioniferax innocua (Pitcher \& Collins, 1991; Yokota et al., 1994; Schumann et al., 1997; Maszenan et al., 1999). All isolates are Gram-positive, non-motile, non-spore-forming chemo-organotrophs. Symbols: +, positive test result; -, negative test result; V, variable; ND, not determined.

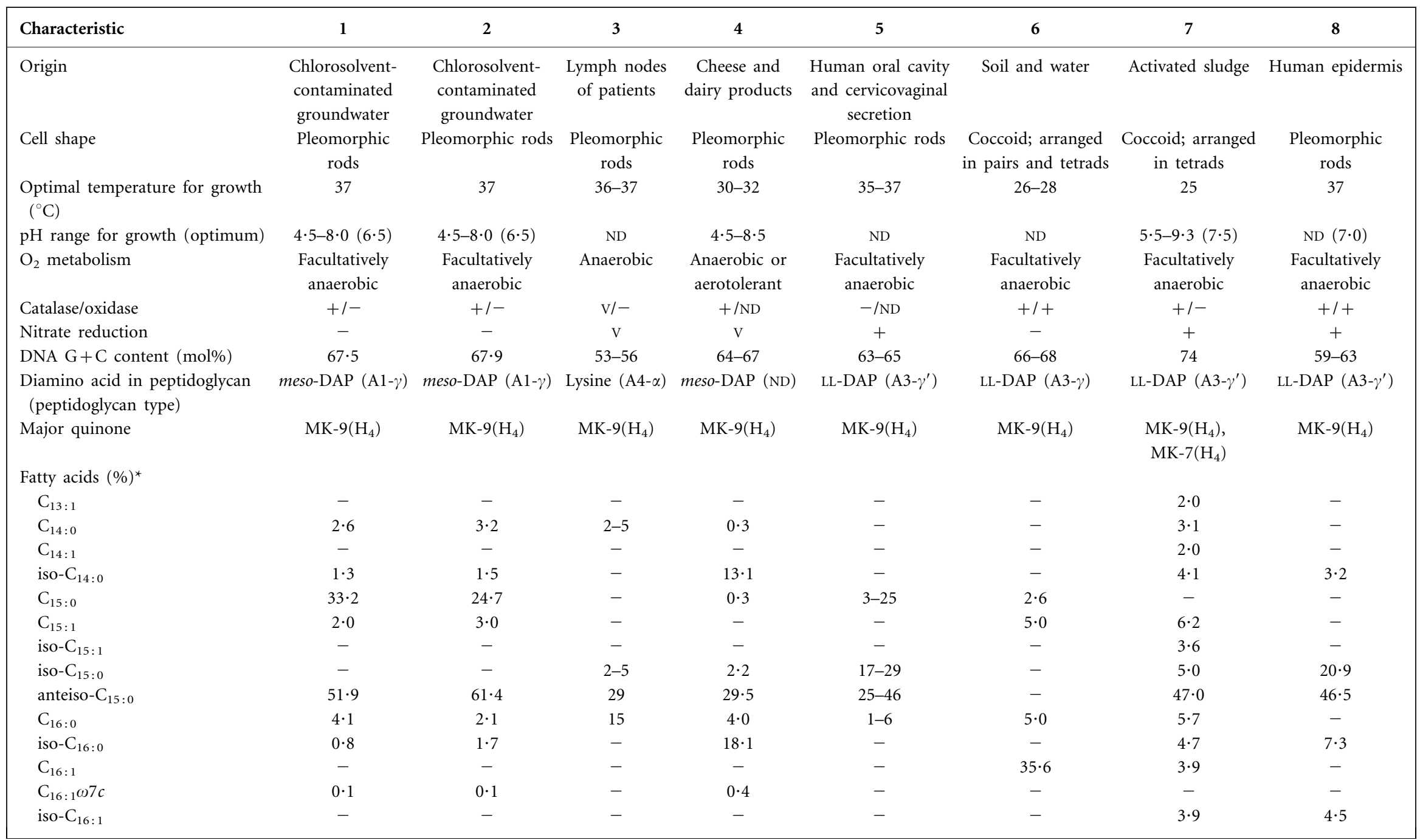




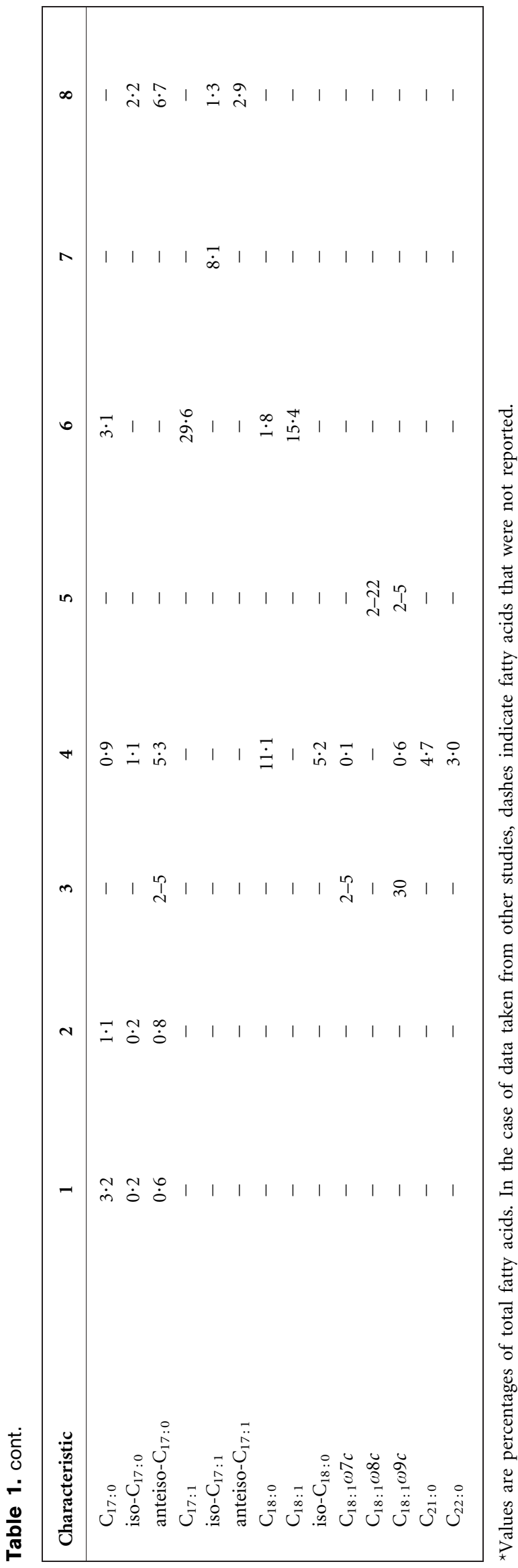

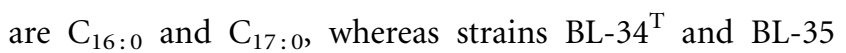
contain anteiso- $\mathrm{C}_{15: 0}$ and $\mathrm{C}_{15: 0}$. Tessaracoccus bendigoensis (Maszenan et al., 1999) and Propioniferax innocua (Yokota et al., 1994), also distantly related to BL- $34^{\mathrm{T}}$ and $\mathrm{BL}-35$, are differentiated from these two strains in containing LL-DAP. T. bendigoensis also contains two menaquinones, MK-9 $\left(\mathrm{H}_{4}\right)$ and MK-7 $\left(\mathrm{H}_{4}\right)$, while strains BL-34 ${ }^{\mathrm{T}}$ and BL-35 possess only MK-9 $\left(\mathrm{H}_{4}\right)$. Other distinguishing characteristics are summarized in Table 1.

On the basis of the phylogenetic, chemotaxonomic and phenotypic features obtained in this study, strains BL- $34^{\mathrm{T}}$ and BL-35 are clearly distinct from other genera in the family Propionibacteriaceae. We propose that strains BL-34 ${ }^{\mathrm{T}}$ and BL-35 be placed within a novel genus, Brooklawnia gen. nov., with Brooklawnia cerclae sp. nov. as the type species.

\section{Description of Brooklawnia gen. nov. Rainey, da Costa and Moe}

Brooklawnia (Brook.law'ni.a. N.L. fem. n. Brooklawnia named after Brooklawn, the contaminated site from which members of the genus were first isolated).

Cells are Gram-positive, non-motile, non-spore-forming pleomorphic rods. Mesophilic, facultatively anaerobic and chemoheterotrophic. Cells are catalase-positive and oxidase-negative, and nitrate is not reduced in PYG media. Propionate and acetate are the predominant products of glucose fermentation. Cell-wall peptidoglycan contains meso-DAP. Major cellular fatty acids are anteiso- $\mathrm{C}_{15: 0}$ and $\mathrm{C}_{15: 0}$. MK-9(H4) is the predominant respiratory quinone. Genomic DNA G + C content is $67 \cdot 5-67 \cdot 9 \mathrm{~mol} \%$. On the basis of $16 \mathrm{~S}$ rRNA gene sequences, the genus belongs to the family Propionibacteriaceae. The type species is Brooklawnia cerclae.

\section{Description of Brooklawnia cerclae sp. nov. Rainey, da Costa and Moe}

Brooklawnia cerclae (cer.cla'e. N.L. gen. fem. n. cerclae of CERCLA, an arbitrary name formed from CERCLA, the acronym for the Comprehensive Environmental Response, Compensation, and Liability Act, which has mandated the clean-up of many hazardous waste sites in the USA).

Displays the following properties in addition to those given in the genus description. Growth occurs between 10 and $40{ }^{\circ} \mathrm{C}$; optimum growth temperature is about $37^{\circ} \mathrm{C}$. Growth occurs between $\mathrm{pH} 4 \cdot 5$ and $\mathrm{pH} 8 \cdot 0$; optimum $\mathrm{pH}$ for growth is $6 \cdot 5$. Growth is not stimulated by the addition of $\mathrm{NaCl}$, but is sustained in the presence of up to $3 \%$ $\mathrm{NaCl}(\mathrm{v} / \mathrm{v})$. Facultative anaerobic growth is supported by fermentation. Cells grow on arabinose, fructose, glucose, galactose, maltose, rhamnose, xylose, ribose, mannose, starch, glycogen, glycerol, mannitol, lactate and pyruvate, but not on acetate, adonitol, cellobiose, cellulose, dulcitol, erythritol, ethanol, fucose, fumarate, inositol, lactose, malate, methanol, raffinose, sorbitol, succinate, sucrose or xylan. 


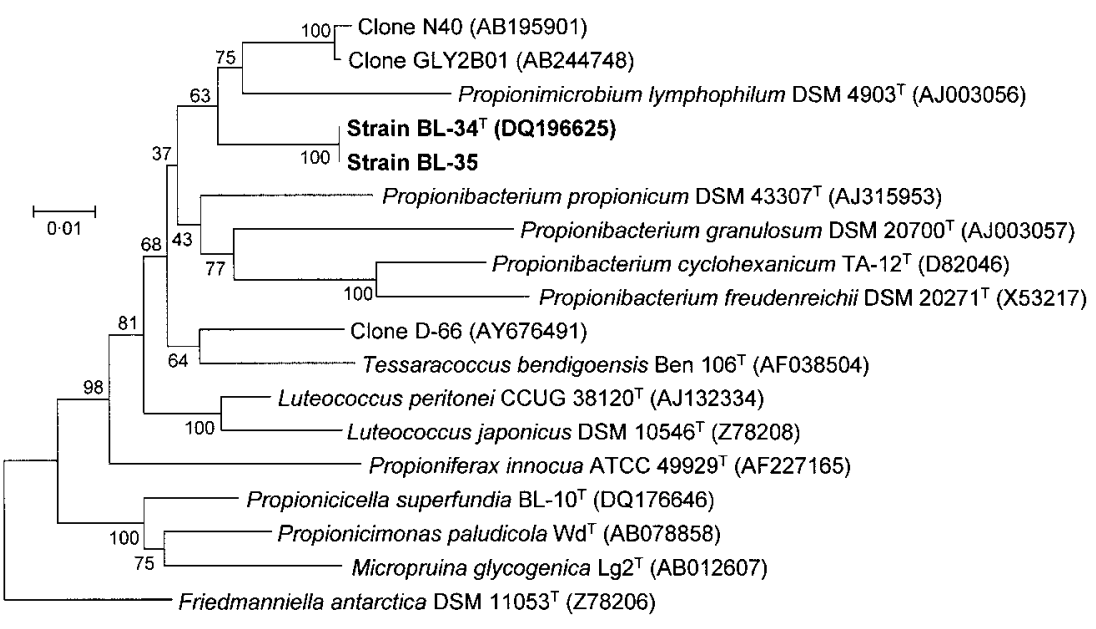

Fig. 1. Phylogenetic relationship of strains $\mathrm{BL}-34^{\top}$ and $\mathrm{BL}-35$ to species of the family Propionibacteriaceae based on 16S rRNA gene sequences, generated by the neighbour-joining method. Bootstrap values (expressed as percentages of 1000 resamplings) are shown at branch points. Bar, 1 substitution per 100 nucleotide positions.
The type strain is strain BL- $34^{\mathrm{T}}\left(=\right.$ LMG $23248^{\mathrm{T}}=$ NRRL B$\left.41418^{\mathrm{T}}\right)$. An additional strain of the species is represented by BL-35 ( = LMG 23249= NRRL B-41419).

\section{Acknowledgements}

This research was funded by the Governor's Biotechnology Initiative of the Louisiana Board of Regents grant BOR\#015 (Enhancement of the LSU Hazardous Substance Research Center Environmental Biotechnology Initiative) and NPC Services, Inc. The authors thank Ms Cindy Henk of the LSU Socolofsky Microscopy Center for assistance with the microscopy. The authors thank Dr Jean Euzéby for assistance with the etymology of the name for the novel species.

\section{References}

Akasaka, H., Izawa, T., Ueki, K. \& Ueki, A. (2003). Phylogeny of numerically abundant culturable anaerobic bacteria associated with degradation of rice plant residue in Japanese paddy field soil. FEMS Microbiol Ecol 43, 149-161.

Clement, T. P., Truex, M. J. \& Lee, P. (2002). A case study for demonstrating the application of U.S. EPA's monitored natural attenuation screening protocol at a hazardous waste site. J Contam Hydrol 59, 133-162.

Collins, M. D., Lawson, P. A., Nikolaitchouk, N. \& Falsen, E. (2000). Luteococcus peritonei sp. nov., isolated from the human peritoneum. Int J Syst Evol Microbiol 50, 179-181.

Collins, M. D., Hutson, R. A., Nikolaitchouk, N., Nyberg, A. \& Falsen, E. (2003). Lueteococcus sanguinis sp. nov., isolated from human blood. Int J Syst Evol Microbiol 53, 1889-1891.

Cummins, C. S. \& Johnson, J. L. (1986). Genus I. Propionibacterium Orla-Jensen 1909, 337 ${ }^{\mathrm{AL}}$. In Bergey's Manual of Systematic Bacterio$\log y$, vol. 2, pp. 1346-1353. Edited by P. H. A. Sneath, N. S. Mair, M. E. Sharpe \& J. G. Holt. Baltimore: Williams \& Wilkins.

Cummins, C. S. \& Moss, C. W. (1990). Fatty acid composition of Propionibacterium propionicus (Arachnia propionica). Int J Syst Bacteriol 40, 307-308.

Felsenstein, J. (2004). PHYLIP (phylogeny inference package), version 3.62. Distributed by the author. Department of Genome Sciences, University of Washington, Seattle, USA.

Guckert, J. B., Antworth, C. P., Nichols, P. D. \& White, D. C. (1985). Phospholipid, ester-linked fatty acid profiles as reproducible assays for changes in prokaryotic community structure of estuarine sediments. FEMS Microbiol Ecol 31, 147-158.

Hall, T. A. (1999). BioEdit: a user-friendly biological sequence alignment editor and analysis program for Windows 95/98/NT. Nucleic Acids Symp Ser 41, 95-98.

Jukes, T. H. \& Cantor, C. R. (1969). Evolution of protein molecules. In Mammalian Protein Metabolism, pp. 21-132. Edited by H. N. Munro. New York: Academic Press.

Kusano, K., Yamada, H., Niwa, M. \& Yamasato, K. (1997). Propionibacterium cyclohexanicum sp. nov., a new acid-tolerant $\omega$ cyclohexyl fatty acid-containing Propionibacterium isolated from spoiled orange juice. Int J Syst Bacteriol 47, 825-831.

Maszenan, A. M., Seviour, R. J., Patel, B. K. C., Schumann, P. \& Rees, G. N. (1999). Tessaracoccus bendigoensis gen. nov., sp. nov., a Gram-positive coccus occurring in regular packages or tetrads, isolated from activated sludge biomass. Int J Syst Bacteriol 49, 459-468.

Mesbah, M., Premachandran, U. \& Whitman, W. B. (1989). Precise measurement of the $\mathrm{G}+\mathrm{C}$ content of deoxyribonucleic acid by highperformance liquid chromatography. Int J Syst Bacteriol 39, 159-167.

Nielsen, P., Fritze, D. \& Priest, F. G. (1995). Phenetic diversity of alkaliphilic Bacillus strains: proposal for nine new species. Microbiology 141, 1745-1761.

Pitcher, D. G. \& Collins, M. D. (1991). Phylogenetic analysis of some LL-diaminopimelic acid-containing coryneform bacteria from human skin: description of Propionibacterium innocuum sp. nov. FEMS Microbiol Lett 84, 295-300.

Rainey, F. A., Ward-Rainey, N., Kroppenstedt, E. \& Stackebrandt, E. (1996). The genus Nocardiopsis represents a phylogenetically coherent taxon and a distinct actinomycete lineage: proposal of Nocardiopsaceae fam. nov. Int J Syst Bacteriol 46, 1088-1092.

Rhuland, L. E., Work, E., Denman, R. F. \& Hoare, D. S. (1955). The behaviour of the isomers of $\alpha, \varepsilon$-diaminopimelic acid on paper chromatograms. J Am Chem Soc 77, 4844-4846.

Schleifer, K. H. \& Kandler, O. (1972). Peptidoglycan types of bacterial cell walls and their taxonomic implications. Bacteriol Rev 36, 407-477.

Schumann, P., Prauser, H., Rainey, F. A., Stackebrandt, E. \& Hirsch, P. (1997). Friedmanniella antarctica gen. nov., sp. nov., an LL-diaminopimelic acid-containing actinomycete from Antarctic sandstone. Int J Syst Bacteriol 47, 278-283.

Smibert, R. M. \& Krieg, N. R. (1981). General characterization. In Manual of Methods for General Bacteriology, pp. 409-443. Edited by 
P. Gerhardt, R. G. E. Murray, R. N. Costilow, E. W. Nester, W. A. Wood, N. R. Krieg \& G. B. Phillips. Washington, DC: American Society for Microbiology.

Stackebrandt, E., Schumann, P., Schaal, K. P. \& Weiss, N. (2002). Propionimicrobium gen. nov., a new genus to accommodate Propionibacterium lymphophilum (Torrey 1916) Johnson and Cummins 1972, $1057^{\mathrm{AL}}$ as Propionimicrobium lymphophilum comb. nov. Int J Syst Evol Microbiol 52, 1925-1927.

Strunk, O. \& Ludwig, W. (1995). ARB - a software environment for sequence data. Department of Microbiology, Technical University of Munich, Munich, Germany.

Sung, Y., Ritalahti, K. M., Sanford, R. A., Urbance, J. W., Flynn, S. J., Tiedje, J. M. \& Löffler, F. E. (2003). Characterization of two tetrachloroethene-reducing, acetate-oxidizing anaerobic bacteria and their description as Desulfuromonas michiganesis sp. nov. Appl Environ Microbiol 69, 2964-2974.

Tamura, T., Takeuchi, M. \& Yokota, A. (1994). Luteococcus japonicus gen. nov., sp. nov., a new gram-positive coccus with LLdiaminopimelic acid in the cell wall. Int J Syst Bacteriol 44, 348-356.
Thompson, J. D., Gibson, T. J., Plewniak, F., Jeanmougin, F. \& Higgins, D. G. (1997). The CLUSTAL_X windows interface: flexible strategies for multiple sequence alignment aided by quality analysis tools. Nucleic Acids Res 25, 4876-4882.

Tindall, B. J. (1990a). A comparative study of the lipid composition of Halobacterium saccharovorum from various sources. Syst Appl Microbiol 13, 128-130.

Tindall, B. J. (1990b). Lipid composition of Halobacterium lacusprofundi. FEMS Microbiol Lett 66, 199-202.

US Environmental Protection Agency (2005). Petro-Processors of Louisiana, Inc. Fact Sheet, pp. 1-6. Washington, DC: US Environmental Protection Agency.

White, D. C., Davis, W. M., Nickels, J. S., King, J. D. \& Bobbie, R. J. (1979). Determination of the sedimentary microbial biomass by extractable lipid phosphate. Oecologia 40, 51-62.

Yokota, A., Tamura, T., Takeuchi, M., Weiss, N. \& Stackebrandt, E. (1994). Transfer of Propionibacterium innocuum Pitcher and Collins 1991 to Propioniferax gen. nov. as Propioniferax innocua comb. nov. Int J Syst Bacteriol 44, 579-582. 